\title{
Research on Forest Ecological Benefit Compensation System of Heilongjiang in China
}

\author{
Fan Jiang ${ }^{1, *}$ \\ ${ }^{1}$ School of Economics and Management, Beijing Jiaotong University, Haidian District, Beijing, 100044, China
}

\begin{abstract}
The forest ecological function zone in Heilongjiang Province is an important barrier for maintaining ecological security in my country. Its forest ecological environment has great influence on the sustainable development of regional economy and society and the ecological security of neighboring regions. Based on reading domestic and foreign related documents on forest ecological benefit compensation, this article firstly discusses the current situation and problems of the forest ecological benefit compensation system in Heilongjiang Province. Secondly, it analyzes the current status of the implementation of the international forest ecological benefit compensation system and draws relevant enlightenment to China. At last, it summarizes and propose countermeasures and suggestions to improve the forest ecological benefit compensation system in Heilongjiang Province.
\end{abstract}

\section{Introduction}

\subsection{Research background and significance}

Heilongjiang Province began to implement the forest ecological benefit compensation fund project in 2004, which has greatly protected the province's forest resources in more than ten years. The quality of the province's forests has been greatly improved, and fires and incidents of damage to forest resources also a lot less. However, with the development of economy, Heilongjiang Province's forest ecological benefit compensation system inevitably adds some urgently needed problems. Compared with the effectiveness of forest ecological compensation in other economically developed provinces, the forest ecological construction in Heilongjiang Province still has many shortcomings.

This article explores the forest ecological benefit compensation system in Heilongjiang Province, which can solve the problem of the deterioration of the forest ecological environment under the traditional economic growth model, promote the protection of forest resources in the province, and promote the coordinated development of different regions, so that the forestry and other related departments and the citizens of society participate more actively in the protection of forest resources.

\subsection{Research methods}

In this paper, by reading numerous domestic and foreign related documents on forest ecological benefit compensation system, comparative analysis of the differences and shortcomings between Heilongiiang Province forest ecological benefit compensation system

\footnotetext{
$\bar{*}$ Corresponding author: 18120516@bjtu.edu.cn
}

and the international forest ecological benefit compensation system, on this basis, analyzes Heilongjiang Province forest ecological benefit compensation system problems in the system and propose countermeasures.

\section{Literature review}

In the 1990s, foreign scholars began to gradually understand the connotation of ecological compensation. Ecological compensation is generally called payment for ecological services in foreign literature. Based on Pigou's theory, ecological compensation is interpreted as a resource transfer method that allows individual and social interests to agree in the use and conservation of ecological resources [1]. Ecological compensation standards are aimed at improving the effective use of ecological compensation. Compensation standards should be set between the cost of ecosystem service providers and the users' income. The compensation standards must be higher than the cost paid and lower than the user's benefits. The cost paid by the ecosystem service provider includes not only the actual cost paid for protecting the ecology, but also its potential opportunity cost [2-3].

Forest ecological benefit compensation refers to the preservation of forest area in order to give full play to the ecological benefits, which is mainly invested and constructed by the state, so that individuals who benefit from forest ecological benefits can pay corresponding fees and compensation funds can get continuous supply [4].

China should use market pricing as a guide to formulate compensation policies for forest ecological benefits, follow voluntary participation guidelines and incorporate market mechanisms, reasonably compensate forest residents for forest ecological benefits, and focus on 
the government's service support functions and the basic role of the market in resource allocation [5].

Many scholars have done less research on the source and use efficiency of ecological compensation funds, and did not specifically propose the criteria to determine the policy implementation area to maximize benefits.

\section{Theoretical basis}

\subsection{Public goods theory}

This theory was first proposed by Samuelson, and the consumer's consumption of a certain item will not affect other people's consumption of this item is a public good. Forest ecological benefits have the attributes of public goods due to the natural resource environment and the ecological services produced.

\subsection{Externality theory}

Economists Nordhaus and Samuelson believe that some production or consumption activities impose irreparable costs on other groups, or generate benefits for others without compensation. On the one hand, destruction of forests or uncontrolled deforestation will affect the service functions of the forest ecosystem which cause negative externalities. On the other hand, forests provide the entire human society with ecological services that do not need to be paid, which produce positive externalities.

\subsection{Property rights theory}

Economist Coase believes that under the premise that transaction costs are zero and property rights are clearly divided, operating a market mechanism can eliminate the influence of externalities and realize the optimal allocation of resources. Dividing the ownership of forest resources is a prerequisite for the possibility of compensation for the operators of public welfare forests. It clarifies the ownership of forest resources. Only those units or individuals that obtain benefits from forest ecological benefits can positively give back to the ecological environment.

\section{Implementation status and problems of forest ecological benefit compensation system in Heilongjiang Province}

\subsection{Implementation status of forest ecological benefit compensation system in Heilongjiang Province}

At present, the existing compensation policies in the area covered by the forest ecological function zone in Heilongjiang Province mainly include compensation measures related to the cultivation and management of forest resources in the natural protection project; the forest ecological benefit compensation fund for the establishment, tending, protection and management of public welfare forests; compensation policies for the conversion of farmland to forests, subsidies for shantytown renovation, and government and social expenditure subsidies. Chinese natural forest protection project has entered the second phase, and the time limit for the second phase is 2011-2020.

\subsubsection{Compensation subject}

The central government and the local government are the main sources of forest ecological compensation funds in Heilongjiang Province. From 2012 to 2015, Heilongjiang Province invested a total of 1.151 billion yuan, including 1.071 billion yuan compensated by the central government, and the provincial financial investment only accounted for $7 \%$.

\subsubsection{Compensation object}

The compensation objects of forest ecological benefits mainly refer to the builders and operators of ecological public welfare forests. The forest ecological compensation objects in Heilongjiang Province are those organizations and staff that manage and protect key protection forests and special-purpose forests, that is, state-owned forest farms, nurseries, forest system protected areas, collective forest farms.

\subsubsection{Compensation legal system}

In 2001, China issued the "Interim Measures for the Administration of Forest Ecological Benefit Subsidy Funds". In 2003, the State Council issued the "Decision on Accelerating Forestry Development". In 2004, it officially implemented the forest ecological benefit compensation fund system nationwide, and promulgated the "Administrative Measures for the Central Finance Forest Ecological Benefit Compensation Fund". In connection with the specific situation, Heilongjiang issued the "Heilongjiang Implementation Rules of the Administrative Measures for the Central Finance Forest Ecological Benefit Compensation Fund ".

\subsubsection{Compensation method}

Most areas mainly implement public financial compensation, and several provinces with higher economic levels have gradually implemented marketbased compensation models and established provinciallevel forest ecological benefit compensation funds. Heilongjiang Province is closely dependent on national compensation and has not yet established a local forest ecological benefit compensation fund.

\subsubsection{Compensation standard}

In 2016, the compensation standard for state-owned public welfare forests was raised to 8 yuan per mu per year, and in 2013, the compensation standard for collectiveowned and individual-owned public welfare forests was raised to 10 yuan per mu. Heilongjiang Province 
implements national public welfare forest compensation standards.

\subsection{Problems existing in forest ecological benefit compensation system in Heilongjiang Province}

Analyzing the implementation status of the forest ecological benefit compensation system in Heilongjiang Province, there are many problems, as shown in Table 1.

Table 1. Problems existing in forest ecological benefit compensation system in Heilongiiang Province.

\begin{tabular}{|c|c|}
\hline $\begin{array}{c}\text { Compensation } \\
\text { system } \\
\text { content }\end{array}$ & The problem \\
\hline $\begin{array}{c}\text { Compensation } \\
\text { subject }\end{array}$ & $\begin{array}{l}\text { The main body of compensation is single } \\
\text { and basically depends on the central } \\
\text { government and provincial government } \\
\text { finances. There is a serious lack of market } \\
\text { compensation and the government's } \\
\text { financial burden is heavy. }\end{array}$ \\
\hline $\begin{array}{c}\text { Compensation } \\
\text { object }\end{array}$ & $\begin{array}{l}\text { The compensation object and scope are } \\
\text { narrow. Only the key public welfare } \\
\text { forests are compensated, while the } \\
\text { general public welfare forests and private } \\
\text { forests in Heilongjiang Province are not } \\
\text { fully compensated. }\end{array}$ \\
\hline $\begin{array}{l}\text { Compensation } \\
\text { legal system }\end{array}$ & $\begin{array}{l}\text { Compared with actual demand, } \\
\text { Heilongjiang Province's ecological } \\
\text { compensation legislation still has } \\
\text { shortcomings. The content of forest } \\
\text { ecological compensation is not clear, the } \\
\text { rights and responsibilities of relevant } \\
\text { stakeholders are not clear, and the } \\
\text { accountability system is lacking. }\end{array}$ \\
\hline $\begin{array}{c}\text { Compensation } \\
\text { method }\end{array}$ & $\begin{array}{l}\text { There is no real establishment of a } \\
\text { compensation system including } \\
\text { government compensation, social } \\
\text { compensation, market compensation and } \\
\text { other compensation methods, and the } \\
\text { market pattern is lacking. }\end{array}$ \\
\hline $\begin{array}{l}\text { Compensation } \\
\text { standard }\end{array}$ & $\begin{array}{l}\text { State-owned forest resources in } \\
\text { Heilongjiang Province occupy a major } \\
\text { position, and the proportion of collective } \\
\text { and individual-owned national public } \\
\text { welfare forests is very low. Although the } \\
\text { national compensation standard has } \\
\text { increased, it is still low for Heilongjiang } \\
\text { Province. }\end{array}$ \\
\hline
\end{tabular}

\section{Current situation and enlightenment of international forest ecological benefit compensation system}

\subsection{Status of international forest ecological benefit compensation system}

\subsubsection{Compensation subject}

The main bodies of international forest ecological benefit compensation include government compensation and market compensation. Germany is dominated by government compensation. The federal government and state governments manage and care for all state-owned forests, and about $1 \%$ of the government's fiscal budget is used for investment in the forest industry. Japan relies mainly on government compensation, and compensation funds mainly come from the central government and local government budgets. Costa Rica has both government compensation and market compensation. The main sources of compensation funds are tax on fossil fuels, carbon sink trading, and bond issuance.

\subsubsection{Compensation object}

The objects of ecological benefit compensation are basically private forests. Private forests make up the bulk of forests in the United States, Germany, Japan, Costa Rica and Brazil. Therefore, internationally, most of the targets of forest ecological benefit compensation are private forest owners with relevant interests.

\subsubsection{Compensation legal system}

Various countries have established relatively complete legal systems for forest ecological benefit compensation. Costa Rica's Forest Law stipulates that the national forest fund compensates private forest owners. Japan formulated and implemented the security forest development plan in 1954 to provide compensation to civilian forests classified as shelter forests, and the security forests are protected by Japanese law. Sweden has made specific plans for compensation of forest ecological benefits in its "Forest Law" and "Environmental Code."

\subsubsection{Compensation method}

Forest ecological benefit compensation methods are mainly government purchase and open market trade. In 2003, Mexico used 20 million dollars of funds for forest compensation ecological services. Japan has established a green feather fund system to use the power of all sectors of society to raise funds for forestry resource construction. Costa Rica conducted its first carbon trading in 1996. It sold Norway worth 2 million dollars to offset 200,000 tons of carbon emissions, and obtained ecological compensation funds by retailing the country's remaining carbon emissions rights on the international market.

\subsubsection{Compensation standard}

Compensation standards for forest ecological benefits in the world are relatively high compared with China. The forest ecological compensation standard in the United States is determined in accordance with the environmental evaluation system. The government compensates more than half of the losses incurred by farmers returning to farmland to protect forest resources, and joins the competition mechanism to formulate compensation standards suitable for the US economy. Germany determines the compensation standard based on the opportunity cost method, the compensation level can basically offset all the losses of farmers. In Japan, the subsidy standard for state-owned forests is more than $50 \%$ 
of the cost of managing and protecting state-owned forests, which is higher than the general plantation forest subsidies.

\subsection{Enlightenment for improving Chinese forest ecological benefit compensation system}

The success of international forest ecological benefit compensation is mainly due to the diversity of compensation entities in most countries, including government compensation and market compensation. Secondly, there are many ways to raise compensation funds, mainly including public payment means and market means. It can provide strong support for forest ecological benefits. Thirdly, a sound ecological compensation legal system can internalize most of the external costs incurred in the development of forest resources. Further, the compensation standards are relatively high, so that relevant stakeholders can actively join the ranks of ecological compensation. For these successful implementation experiences, our country can selectively learn from them and apply them after reforms based on national conditions.

\section{Conclusions and recommendations}

\subsection{Conclusions}

The research of this thesis draws the following conclusions. (1) The main body of forest ecological benefit compensation is diversified in the world, and the compensation objects are mainly private forests. There are many sources of compensation funds, the compensation standards are also high, and there is a complete compensation legal system. (2) There are still many problems in the forest ecological benefit compensation system in Heilongjiang Province. (3) Improving the forest ecological benefit compensation system in Heilongjiang Province plays an important role in the protection of Heilongjiang Province's ecological construction.

\subsection{Suggestions on improving the compensation system of forest ecological benefits in Heilongjiang Province}

\subsubsection{Expand the scale of provincial public welfare forest management and protection}

Analyzing the current situation of Heilongjiang Province, the scope of compensation for forest ecological benefits from the central government should be expanded to compensate for the general public welfare forests in Heilongjiang Province. The ownership of newly-emerging private forests should be clearly defined in a timely manner to alleviate conflicts among stakeholders.

\subsubsection{Expand the sources of compensation funds}

Through analysis, it can be seen that the methods of raising compensation funds in various countries are diversified, and Heilongjiang Province can selectively learn from it. Specific methods include levying ecological taxes and strictly following the principle of compensation for beneficiaries, launching forest carbon sink trading projects, establishing reasonable evaluation standards for reducing greenhouse gas emissions and gradually building a forest carbon sink trading market.

\subsubsection{Ensure compensatory funds are earmarked for special purposes}

In the specific allocation and use of forest ecological compensation financial funds, it is necessary to implement special funds for special purposes and allocate them to ecologically fragile areas that urgently need funds. Strictly abide by the "Budget Law" and supervise and implement the requirements in the "Heilongjiang Implementation Rules of the Administrative Measures for the Central Finance Forest Ecological Benefit Compensation Fund" to prevent relevant departments from deliberately delaying the distribution, occupying or embezzling funds.

\subsubsection{Improve the economic incentive mechanism of forest ecological benefit compensation in Heilongjiang Province}

The government can use the forest ecological compensation horizontal transfer payment fund, that is mutual adjustment of compensation funds between organizations at the same level, and can also implement preferential policies for tax reduction and exemption, subsidies for ecological protection projects, and lowinterest preferential loans for ecological project applicants incentive policies so that those involved in the management and protection of public welfare forests actively participate in forest ecological compensation.

\subsubsection{Improve the legal system of forest ecological benefit compensation in Heilongjiang Province}

Improve the forest ecological benefit compensation system, improve the relevant departments' mastery of the legalization of the forest ecological benefit compensation system, establish an efficient legal incentive and restraint guarantee system, so that the relevant work process of compensation can be followed by law.

\section{References}

1. R. Muradian, E. Corbera, U. Pascual, et al. Ecol Econ, 69:1202-1208 (2010)

2. C. Munoz-Pina, A. Guevara, et a1. Ecol Econ, 65:725736 (2008)

3. P. Thu Thuy, B. M Campbell, S. Garnet. Asia Pacific J. Public Adm., 31:117-133 (2014)

4. X.Q. Ren. Flowers, 14:172-173 (2017) (in Chinese)

5. L.P. Xu, G.N. Zhao, Z.L. Dai. Agric Econ, 37:101109+112 (2016) (in Chinese) 